\title{
Prevalence and risk factors of otitis media with effusion in primary school children in Mersin
}

\author{
Mersin'de ilkokul çocuklarında efüzyonlu otitis media prevalansı ve risk \\ faktörleri
}

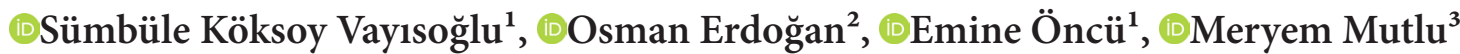 \\ ${ }^{1}$ Mersin University, Nursing Faculty, Department of Public Health Nursing, Mersin, Turkey \\ ${ }^{2}$ Şanlıurfa Training and Research Hospital, Department of Otorhinolaryngology, Şanlıurfa, Turkey \\ ${ }^{3}$ Mersin University, Medical Science Institute, Mersin, Turkey
}

Cite this article as/Bu makaleye atıf için: Köksoy Vayısoğlu S, Erdoğan O, Öncü E, Mutlu M. Prevalence and risk factors of otitis media with effusion in primary school children in Mersin. J Health Sci Med 2020; 3(4): 448-453.

\begin{abstract}
Aim: To investigate the prevalence of otitis media with effusion (OME) and related risk factors among primary school children in Mersin. Material and Method: The study was conducted at eight primary government schools in the distinct socioeconomic district between October 2018 and December 2018. Using the combined physical examination and otoscopic evaluations, a total of 960 children included the study.

Findings: Of the children who were screened, $53.2 \%$ were girls and the mean age was $7.57 \pm 0.45$ years (min:5-max: 11 years). In this study, otitis media with effusion prevalence was $2.6 \%$ ( 20 of 761 children) and all children had bilateral otitis media with effusion. There was no statistically significant difference between the presence of otitis media with effusion and the number of people at home, incoming level, month of birth, birth weight, duration of breastfeeding, age average, class, gender, smoking in the house, presence of hearing loss in the family, history of otitis in the family, use of pacifier, use of baby bottle, presence of allergy, previous history of otitis, the presence of open mouth, snoring and tonsil grades.

Conclusion: Although the low prevalence of otitis media with effusion in our study, considering that otitis media with effusion and its possible preventive severe complications, screening for otitis media with effusion should be a part of preventive health services, particularly for primary school children.
\end{abstract}

Keywords: Children, school nursing, otitis media with effusion, prevalence, primary schools

\section{ÖZ}

Amaç: Mersin'deki ilkokul çocukları arasında efüzyonlu otitis media (EOM) prevelansını ve ilgili risk faktörlerini araştırmak.

Gereç ve Yöntem: Çalışma Ekim 2018-Aralık 2018 tarihleri arasında farklı sosyoekonomik bölgedeki sekiz ilköğretim okulunda gerçekleştirildi. Fizik muayene ve otoskopik değerlendirmeler birlikte kullanılarak toplam 960 çocuk çalışmaya dahil edildi.

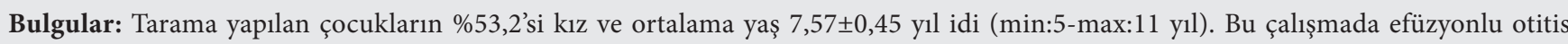
media prevalansı \%2,6 idi (761 çocuğun 20’si) ve tüm çocuklarda bilateral efüzyonlu otitis media vardı. efüzyonlu otitis media varlığı ile evdeki kişi sayısı, gelir düzeyi, doğum ayı, doğum kilosu, emzirme süresi, yaş ortalaması, sınıf, cinsiyet, evde sigara kullanımı, ailede işitme kaybı varlığı, ailede otit öyküsü, emzik kullanımı, biberon kullanımı, alerji varlığı, önceki otit öyküsü, açık ağız varlığı, horlama ve bademcik evreleri arasında istatistiksel olarak anlamlı bir fark yoktu.

Sonuç: Çalışmamızda efüzyonlu otitis media prevalansı düşük olmasına rağmen, efüzyonlu otitis media ve olası önleyici ciddi komplikasyonları düşünüldügünde, efüzyonlu otitis media taraması özellikle ilkokul çocukları için koruyucu sağlık hizmetlerinin bir parçası olmalıdır.

Anahtar Kelimeler: Çocuklar, hemşirelik, efüzyonlu otitis media, prevalans, ilkokul 


\section{INTRODUCTION}

Hearing loss in childhood occurring from birth to late childhood and it can be classified as conductive, sensorineural and mixed type. The signs of hearing loss include delays in speech or language, vestibular problems and academic failure in children. Also hearing loss can affect children's social interactions and academic life $(1,2)$. Early diagnosis of hearing loss is essential for warranting early intervention and development of normal language and academic skills in children. For this reason, hearing screening and ear examination are important in schoolage children and appropriate follow-up care should be provided to detected children $(3,4)$.

Otitis media with effusion (OME) is defined as the accumulation of fluid in the middle ear cavity without any signs and symptoms of acute infection and it causes conductive type hearing loss. Hearing loss in children is most commonly related to OME in developed countries. Hearing loss may affect speech, cognitive, and psychological development of the children. Since OME symptoms can be insidious, diagnosis is difficult and often delayed. The disease is an important public health problem because there are many risks of complications such as tympanosclerosis, chronic otitis media (COME), retraction pockets and adhesive otitis media (5). There are many environmental risk factors including smoking, poor socio-economic conditions, seasonal conditions, daycare, race, sex, adenoid tissue hypertrophy, eustachian tube dysfunction, immunodeficiency, allergy, mastoid pneumatization and craniofacial abnormalities in the development of OME. Epidemiologic data may be contributory and complementary in determining the etiopathogenesis of OME. There are several studies reported the prevalence of $\mathrm{OME}$ as 1.3 to $31.3 \%$ in primary school children depending on the countries $(2,6-8)$.

The school health nurse serves an important role in the overall health and education of the children in their school and hearing screening in school-age children is a part of this role. Handling hearing loss early offers better results and an opportunity for success at school. Since the most common cause of conductive hearing loss in children is OME, it is an important health problem in school-age children (9). With this viewpoint, the study aimed to determine the prevalence of OME in primary school children in Mersin and to investigate the association between OME and related risk factors.

\section{MATERIAL AND METHOD}

\section{Patient Selection}

This cross-sectional study was conducted by Department of Public Health Nursing and Otorhinolaryngology between October 2018 and December 2018. This study was approved by the Ethics Committee of Mersin University. There were approximately 120000 children in 139 primary schools covering the first four years of education. The minimum number of samples (768) was calculated by statistical software (Epi-Info version 7; www. cdc.gov). The population of the universe was 120000 and the prevalence of OME was 10\%, 95\% confidence interval, $3 \%$ sampling error and design effect as 2 . A total of 960 students sampled due to predict of $20 \%$ loss. In this study, multistage sampling method was used. Each district was evaluated as a cluster and location of schools divided to a low, medium and high level according to land price of districts. Each school was selected from each district on low and high socioeconomic level (among the lowest and highest of $20 \%$ segment) by simple random sampling method. One class was determined with randomly from each first, second, third and fourth's class on each school. There were 960 students in 32 classes in eight schools included in the study and 761 students receiving parental consent were included in the study. The participation rate was $79.3 \%$.

\section{Questionnaire}

In this study, data collected with middle ear disorders risk factors questionnaire and physical examination findings. Twenty-one questions included in this questionnaire which includes the child's health status, breastfeeding, bottle-pacifier use, number of individuals living at home, smoking in the house, family ear disease history accordance with the literature (6-8). The questionnaire and the parental leave form were sent to the families by the school nurse the day before the examination. Children of the families were examined who signed the informed consent form and completed the form.

\section{Examination}

All the children were examined in the suitable place of each school by otorhinolaryngology specialist. Physical examination was carried out by otoscope (ear and nasal examination) and abeslang (oral cavity examination). Children with obstructed external ear canal by cerumen excluded from the study. The ear examination findings divided as normal ear, OME, COME and adhesive otitis media. Oral cavity examination findings divided as tonsillar hypertrophy, according to Brodsky (from grade 0 to grade 4 ). The children diagnosed as OME were referred to the hospital for follow-up and treatment.

\section{Statistical Analysis}

The data were analyzed by E-Picos (Medicres.org) using descriptive statistics as number, percentage, arithmetic mean, median (25\%-75\%) and materiality test as Chisquare test. $\mathrm{p} \leq 0.05$ was considered significant. 


\section{RESULTS}

In this study, $45.9 \%$ of the schools with low socioeconomic status, and $54.1 \%$ of with high socioeconomic status. According to classes of students, $26.3 \%$ of the students were $1^{\text {st }}$ grade, $23.8 \%$ were $2^{\text {nd }}$ grade, $22.5 \%$ were $3^{\text {rd }}$ grade and $27.5 \%$ were $4^{\text {th }}$ grade (Table $\mathbf{1}$ ).

\section{Table 1. Introductory features of children}

\begin{tabular}{|llll|}
\hline & & n & \% \\
\hline Location of schools & Low & 349 & 45.9 \\
according to incoming level & High & 412 & 54.1 \\
Class & 1. class & 200 & 26.3 \\
& 2. class & 181 & 23.8 \\
& 3. class & 171 & 22.5 \\
Sex & 4. class & 209 & 27.5 \\
& Female & 405 & 53.2 \\
& Male & 356 & 46.8 \\
\hline
\end{tabular}

Of the children who were screened, $53.2 \%$ were girls and the mean age was $7.57 \pm 0.45$ years (min: 5-max: 11 years). The average of income level of family $(n=578)$ 2334.82 $\pm 67.172 \mathrm{TL}$ (min: 60-max: $13000 \mathrm{TL}$ ). The average number of people living at home $(\mathrm{n}=723) 4.90 \pm 0.06$ (min: 2-max: 12 person). The average birth weight of the children $(\mathrm{n}=710) 3198.50 \pm 23.18 \mathrm{gr}$ (min: 800-max: 6000, median: $3200 \mathrm{gr}$ ) and average breastfeeding time ( $\mathrm{n}=615) 15.63 \pm 0.36$ months (min: 1, max: 48, median: 15 months).

In this study, OME prevalence was 2,6\% (20 of 761) and all children had a bilateral OME. Also, one child had bilateral perforated tympanic membrane $(0.1 \%)$ and six children had a retraction of the tympanic membrane (1.5\%) (Table 2).

\begin{tabular}{|c|c|c|c|}
\hline \multicolumn{2}{|l|}{ Examination finding } & $\mathbf{n}$ & $\%$ \\
\hline \multirow{3}{*}{$\begin{array}{l}\text { Otoscopic examination } \\
(\mathrm{n}: 761)\end{array}$} & Normal & 698 & 91.8 \\
\hline & Pathologic & 27 & 3.5 \\
\hline & $\begin{array}{l}\text { Could not be } \\
\text { assessed }\end{array}$ & 36 & 4.7 \\
\hline $\begin{array}{l}\text { Otitis media with } \\
\text { effusion (n:725) }\end{array}$ & Yes & 20 & 2.7 \\
\hline $\begin{array}{l}\text { Perforated tympanic } \\
\text { membrane (n:725) }\end{array}$ & Yes & 1 & 0.1 \\
\hline $\begin{array}{l}\text { Retraction of tympanic } \\
\text { membrane (n:725) }\end{array}$ & Yes & 6 & 0.8 \\
\hline \multirow{6}{*}{ Tonsillar size (n:761) } & Grade- 0 & 172 & 22.6 \\
\hline & Grade-1 & 328 & 43.2 \\
\hline & Grade-2 & 183 & 24.0 \\
\hline & Grade-3 & 49 & 6.4 \\
\hline & Grade-4 & 3 & 0.4 \\
\hline & Tonsillectomised & 26 & 3.4 \\
\hline
\end{tabular}

There was no significant difference between the presence of OME and the number of people at home, the amount of income, month of birth, birth weight, duration of breastfeeding, age average, income status, class, gender, smoking in the house, presence of hearing loss in the family, history of otitis in the family, use of pacifier, use of baby bottle, presence of allergy, previous history of otitis, the presence of open mouth, snoring and tonsillar grades (Table 3).

\begin{tabular}{|c|c|c|c|}
\hline & \multicolumn{2}{|c|}{ Yes, n (\%) } & No, n (\%) \\
\hline $\begin{array}{l}\text { Is anyone smoking in } \\
\text { the house? (n:758) }\end{array}$ & \multicolumn{2}{|c|}{$330(43.5)$} & $428(56.5)$ \\
\hline $\begin{array}{l}\text { Is mother smoking? } \\
\text { (n:758) }\end{array}$ & \multicolumn{2}{|c|}{$166(21.9)$} & $592(78.1)$ \\
\hline $\begin{array}{l}\text { Is father smoking? } \\
\text { (n:758) }\end{array}$ & \multicolumn{2}{|c|}{$419(55.3)$} & $339(44.7)$ \\
\hline $\begin{array}{l}\text { Hearing loss in } \\
\text { family? (n:746) }\end{array}$ & \multicolumn{2}{|c|}{$72(9.7)$} & $674(90.3)$ \\
\hline \multirow{3}{*}{$\begin{array}{l}\text { Who has hearing loss? } \\
(\mathrm{n}: 73)\end{array}$} & Father & $25(34.2)$ & \\
\hline & Mother & $29(39.7)$ & \\
\hline & Sibling & $19(26.1)$ & \\
\hline $\begin{array}{l}\text { Otitis media in } \\
\text { family? (n:717) }\end{array}$ & \multicolumn{2}{|c|}{$100(13.9)$} & $617(86.1)$ \\
\hline \multirow{3}{*}{$\begin{array}{l}\text { Who has otitis media? } \\
(\mathrm{n}: 100)\end{array}$} & Father & $19(19.0)$ & \\
\hline & Mother & $34(34.0)$ & \\
\hline & Sibling & $47(47.0)$ & \\
\hline Breastfeeding (n:745) & & $703(94.4)$ & $42(5.6)$ \\
\hline Pacifier usage (n:731) & & $274(37.5)$ & $457(62.5)$ \\
\hline Bottle feeding? (n:741) & & $484(65.3)$ & $257(34.7)$ \\
\hline $\begin{array}{l}\text { Has your child ever } \\
\text { had otitis media? } \\
\text { (n:730) }\end{array}$ & & $100(13.7)$ & $630(86.3)$ \\
\hline $\begin{array}{l}\text { Does your child have } \\
\text { hearing loss? (n:725) }\end{array}$ & & $23(3.2)$ & $702(96.8)$ \\
\hline $\begin{array}{l}\text { Recurrent upper } \\
\text { airway infection } \\
(\mathrm{n}: 720)\end{array}$ & & $270(37.5)$ & $450(62.5)$ \\
\hline \multirow{2}{*}{$\begin{array}{l}\text { Open mouth sleeping } \\
\text { (n: } 736)\end{array}$} & Always & $105(14.3)$ & \multirow{2}{*}{$330(44.8)$} \\
\hline & Only when sick & $301(40.9)$ & \\
\hline \multirow{2}{*}{ Snoring (n:736) } & Always & $66(9.0)$ & \multirow{2}{*}{$459(62.4)$} \\
\hline & Only when sick & $211(28.7)$ & \\
\hline \multirow{2}{*}{ Sleep apnea (n:734) } & Always & $12(1.6)$ & \multirow{2}{*}{$620(84.5)$} \\
\hline & Only when sick & $102(13.9)$ & \\
\hline
\end{tabular}

\section{DISCUSSION}

This study is an epidemiologic investigation of the prevalence of OME in school-age children, another ear disease, and tonsillar hypertrophy. OME is one of the most common health problems seen in children and it may lead to sequelae or complications such as hearing loss, delay of speech and language. These probable complications may be prevented by early diagnosis of OME. The etiology of OME is multifactorial and various factors effected this process (6-8). 
In this study, OME prevalence in primary school children was $2.6 \%$ and this rate was low as according to previous literature from Turkey and other countries. The reported prevalence of OME in Turkey is variable depending on the cities. The reported prevalence was $11.2 \%$ to $13.3 \%$ in Ankara (10-12), $7 \%$ to $8.7 \%$ in Istanbul $(13,14), 16.9 \%$ in Denizli (15), 6.5\% in Kahramanmaras (8), $11.44 \%$ in Trabzon (16), 14,5\% in Diyarbakir (4). Our prevalence rates were lower than those reported results and various climatic and environmental factors may explain this low rate. Also, we made diagnosis of OME only by otoscopic examination, if portable tympanometry was used as auxiliary method the rate might have been different. The fact that now parents are conscious and that children are diagnosed earlier can also explain these low rates. Also, some public health initiatives, such as prevention through vaccination, may be responsible for reducing the OME rates. In our study, the incidence of OME was lower than in previous studies, suggesting that vaccination programs may be successful. Also, the low prevalence of OME in our study support the recommendations of guideline that clinicians should not routinely screen children for OME who are not at risk for OME (17).

In the literature, the prevalence of OME is variable on the world, ranging from 1.3 to $31.3 \%$, depending on the countries. In a study from China, the OME prevalence was found $1.3 \%$, while in a study from Kuwait, it was found $31.3 \%(18,19)$. The prevalence rates reported in other studies were as follows: $6.5 \%$ in the Greece (20), 9.5\% in the Netherlands (21), 10\% in Easter Island (22), 13.8\% in Saudi Arabia (23), and 2.2\% in Hong Kong (24). Our prevalence rate was $2.6 \%$ in the similar age group. These different results may be related to climatic and environmental factors. Also, some genetic predisposition may be involved. For example, some studies suggest that the Eustachian tube functions may better in the African races and therefore, low rates of OME seen in this region $(25,26)$.

Some authors found that OME was encountered more frequently in boys or girls, whereas others found no differences (18-22). In this study, there is no gender difference in the prevalence of OME. This result is due to the low rate of OME prevalence in our study.

In our study found no relationship between OME and duration of breastfeeding. The most likely explanation for this is that in our study, there were children who have been breastfed for at least one year and breastfeeding is protective against middle ear infections. Breastfeeding of children for at least three months from birth reduces the risk of developing middle ear infections (27). Also, there was no difference in middle ear infections between the breastfed and non-breastfed children. This finding can be explained by our study includes a few children never breastfed, because breast-feeding is very common in Turkey.
Feeding bottle or pacifier usage may play an etiologic role in the development of OME $(28,29)$. In our study found no relationship between OME and feeding bottle or pacifier usage. However, while our results showed a predisposition of increased OME with bottle use, it was not statistically significant. This could be explained by the low prevalence of OME in our study.

Recurrent upper respiratory infections and passive smoking increase the risk of middle ear infection by promoting colonization with pathogens $(2,3)$. The effect of smoke on mucociliary function and consequent risk for OME has been known, but in our study, there is no statistically significant difference between the children had smoking and non-smoking parents.

Some studies show that low incoming level and poor sociodemographic features are risk factors for developing OME related to overcrowding in house, malnutrition, and poor hygiene of home $(7,8)$. Although epidemiologic studies suggest that genetic susceptibility to middle ear diseases such as OME and COME, environmental factors and population characteristics should be taken into consideration. In our study, the prevalence of OME is higher at low incoming level, but this difference statistically insignificant.

Adenotonsillar pathology may be a risk factor for developing OME (30). In this study, we did not evaluate the adenoid size due to this examination needs the endoscope; therefore, we evaluated the only tonsillar sizes. In our study, there was no significant difference between the presence of OME and the presence of open mouth, snoring and tonsil grades. In this study, there is no significant difference between the OME and tonsillar sizes. This issue due to low OME prevalence of our study population.

There are some limitations in our study. First, OME can be diagnosed by otoscopy in the clinic, but if there is any diagnostic doubt, auxiliary diagnostic methods such as pneumatic otoscopy, otomicroscopy, tympanometry and audiometry can be used. In our study, auxiliary diagnostic methods could not be used because otoscopic examinations were performed in schools. Second, children can be more affected auditory and cognitively in chronic OME, while acute OME may appear physiologically after URI and regress spontaneously and its negative effect on the child may be minimal. The distinction between acute and chronic OME can be made with clinical follow-up. We recorded instant condition of the middle ear during the examination, but not differentiate between acute and chronic OME. 


\section{CONCLUSION}

Though the low prevalence of OME in our study, considering that $\mathrm{OME}$ and its possible preventive severe complications screening for OME should be a part of preventive health services particularly for primary school children. The low prevalence of OME in our study support the recommendations of guideline that clinicians should not routinely screen children for OME who are not at risk for OME. However, identifying children with symptoms that can be associated with OME, such as hearing difficulties, vestibular problems, poor academic performance, behavioral problems, or ear discomfort, is still important issue.

\section{ETHICAL DECLARATIONS}

Ethics Committee Approval: The study was carried out with the permission of Ethics Committee of Mersin University (Permission granted: 07.11.2018, Decision no: $2018 / 450$ )

Informed Consent: Informed consent was obtained from the parents of the children evaluated in this study.

Referee Evaluation Process: Externally peer-reviewed.

Conflict of Interest Statement: The authors have no conflicts of interest to declare.

Financial Disclosure: The authors declared that this study has received no financial support.

Author Contributions: All of the authors declare that they have all participated in the design, execution, and analysis of the paper, and that they have approved the final version.

\section{REFERENCES}

1. Schilder AG, Chonmaitree T, Cripps AW, et al. Otitis media. Nat Rev Dis Primers 2016; 2: 16063.

2. DeAntonio R, Yarzabal JP, Cruz JP, Schmidt JE, Kleijnen J. Epidemiology of otitis media in children from developing countries: a systematic review. Int J Pediatr Otorhinolaryngol 2016; 85: 65-74.

3. Erdivanli OC, Coskun ZO, Kazikdas KC, Demirci M. Prevalence of otitis media with effusion among primary school children in Eastern Black Sea, in Turkey and the effect of smoking in the development of otitis media with effusion. Indian J Otolaryngol Head Neck Surg 2012; 64: 17-21.

4. Guzel R, Meric F, Toprak SF, Yorgancilar AE, Gün R. Prevalence and risk factors of otitis media with effusion in primary school and kindergarten children in provincial and district centers of Diyarbakir. J Med Updates 2012; 2: 1-8.

5. Kaspar A, Newton O, Kei J, Driscoll C, Swanepoel W, Goulios $\mathrm{H}$. Prevalence of ear disease and associated hearing loss among primary school students in the Solomon Islands: Otitis media still a major public health issue. Int J Pediatr Otorhinolaryngol 2018; 113: 223-8.
6. Kiris M, Muderris T, Kara T, Bercin S, Cankaya H, Sevil E. Prevalence and risk factors of otitis media with effusion in school children in Eastern Anatolia. Int J Pediatr Otorhinolaryngol 2012; 76: $1030-5$.

7. Ozkiriș M, Kapusuz Z, Saydam L. The prevalance of middle ear diseases among 7- to 13-year-old primary school students in Yozgat province. Turk J Pediatr 2012; 54: 493-6.

8. Okur E, Yildirim I, Akif Kilic M, Guzelsoy S. Prevalence of otitis media with effusion among primary school children in Kahramanmaras, in Turkey. Int J Pediatr Otorhinolaryngol 2004; 68: 557-62.

9. Sekhar DL, Beiler JS, Schaefer EW, et al. Certified school nurse perspectives on state-mandated hearing screens. J Sch Health 2016; 86: 612-9.

10. Jones AL, Lambert AW, Barnett M. Nursing students: Training and maintaining universal newborn hearing screening knowledge. Nurse Educ Pract 2018; 32: 72-7.

11. Ozbilen S, Beder E, Akyildiz N, Koybasoglu A, Goksu N. Ankara Balgat cevre ilkokul ögrencileri arasinda kulak burun bogaz hastaliklari prevalansi. Proceedings of the 17th Turkish Otorhinolaryngology National Congress; 1985; Istanbul, Turkey. 1985. pp. 128-33.

12. Goksu A. Park Egitim Saglik ocagi bolgesine bagli ilkokullarda sekretuar otitis media prevalans arastirmasi. A.Ü. Halk Sağllğ Departmanı, Doktora Tezi. 1992.

13. Gultekin E, Develioğlu ON, Yener M, Ozdemir I, Kulekci M. Prevalence and risk factors for persistent otitis media with effusion in primary school children in Istanbul, Turkey. Auris Nasus Larynx 2010; 37: 145-9.

14.İnanlı S, Özer E, Öztürk Ö, et al. Istanbul'da okul öncesi ve okul çağındaki çocuklarda sekretuar otitis media prevalansı ve risk faktörleri. Turk Arch Otorhinolaryngol 2000; 38: 9-16.

15. Özüer MZ, Topuz B, Kara CO, Bayramoğlu I. Denizli merkez anaokullarında sekretuar otitis media prevalansı ve risk faktörleri. Kulak Burun Bogaz Ihtis Derg 1999; 6: 63-5.

16. Caylan R, Bektas D, Atalay C, Korkmaz O. Prevalence and risk factors of otitis media with effusion in Trabzon, a city in northeastern Turkey, with an emphasis on the recommendation of OME screening. Eur Arch Otorhinolaryngol 2006; 263: 404-8.

17. Rosenfeld RM, Shin JJ, Schwartz SR, et al. Clinical practice guideline: otitis media with effusion (update). Otolaryngol Head Neck Surg 2016; 154: 1-41.

18. Rushton HC, Tong MC, Yue V, Wormald PJ, van Hasselt CA. Prevalence of otitis media with effusion in multicultural schools in Hong Kong. J Laryngol Otol 1997; 111: 804-6.

19. Holmquist J, Al Fadala S, Qattan Y. Prevalence of secretory otitis media among school children in Kuwait. J Laryngol Otol 1987; 101: 116-9.

20.Apostolopoulos K, Xenelis J, Tzagaroulakis A, Kandiloros D, Yiotakis J, Papafragou K. The point prevalence of otitis media with effusion among school children in Greece. Int J Pediatr Otorhinolaryngol 1998; 44: 207-14.

21. Schilder AG, Zielhuis GA, Van Den Broek P. The otological profile of a cohort of Dutch 7.5-8-year-olds. Clin Otolaryngol Allied Sci 1993; 18: 48-54.

22. Goycoolea HG, Goycoolea MV, Farfan CR. Racial and familial factors in otitis media. A point prevalence study on Easter Island. Arch Otolaryngol Head Neck Surg 1988; 114: 147-9.

23.El-Sayed Y, Zakzouk S. Point prevalence of type B tympanogram in Riyadh. Int J Pediatr Otorhinolaryngol 1995; 31: 53-61.

24. Tong MC, Yue V, Ku PK, Lo PS, van Hasselt CA. Screening for otitis media with effusion to measure its prevalence in Chinese children in Hong Kong. Ear Nose Throat J 2000; 79: 626-30. 
25. Okeowo PA. Observations on the incidence of secretory otitis media in Nigerian children. J Trop Pediatr 1985; 31: 295-8.

26. Halama AR, Voogt GR, Musgrave GM. Prevalence of otitis media in children in a black rural community in Venda (South Africa). Int J Pediatr Otorhinolaryngol 1986; 11: 73-7.

27. Karunanayake CP, Albritton W, Rennie DC, et al. Ear infection and related risk factors in first nations and rural school-aged Canadian children. Int J Pediatr 2016; 2016: 1523897.

28.Salah M, Abdel-Aziz M, Al-Farok A, Jebrini A. Recurrent acute otitis media in infants: analysis of risk factors. Int J Pediatr Otorhinolaryngol 2013; 77: 1665-9.

29. Owen MJ, Baldwin CD, Swank PR, Pannu AK, Johnson DL, Howie VM. Relation of infant feeding practices, cigarette smoke exposure, and group child care to the onset and duration of otitis media with effusion in the first two years of life. J Pediatr 1993; 123: 702-11.

30. Els T, Olwoch IP. The prevalence and impact of otitis media with effusion in children admitted for adeno-tonsillectomy at Dr George Mukhari Academic Hospital, Pretoria, South Africa. Int J Pediatr Otorhinolaryngol 2018; 110: 76-80. 